\title{
INFLUENCE OF THE HYDROELECTRIC POWER PLANT OF PASSO FUNDO LAKE (RS, BRAZIL) ON LOCAL RAINFALL PATTERN
}

\author{
SANCHES, Fabio de Oliveira - fsanches.73@gmail.com \\ Universidade Federal do Triangulo Mineiro / UFTM
}
FERRAZO, Suéllen Tonatto- suellenferrazzo@hotmail.com
Universidade Federal da Fronteira Sul/ UFFS
SILVA, Roberto Valmir - roberto.dasilva@gmail.com Universidade Federal da Fronteira Sul/ UFFS
CHECHI, Leonardo - leonardochechi@gmail.com Universidade Federal da Fronteira Sul/ UFFS

FERREIRA, Ricardo Vicente - rcrdvf@gmail.com Universidade Federal do Triangulo Mineiro / UFTM

\begin{abstract}
The present study examined the influence of the Hydroelectric Power Plant (HPP) of Passo Fundo dam lake on local rainfall pattern. Daily rainfall data were obtained from the National Water Agency for two different periods: prior to the lake filling, 19601970 (pre-filling) and later to the lake filling, 1971-1981 (post-filling). Statistical measures (mean, maximum, minimum, standard deviation and coefficient of variation) and the Student's t-test were applied to both periods regarding the monthly rainfall total. The Student's t-test was also applied to days with cumulative rainfall greater than $1 \mathrm{~mm}$, $10 \mathrm{~mm}, 20 \mathrm{~mm}, 30 \mathrm{~mm}, 50 \mathrm{~mm}, 80 \mathrm{~mm}$ and $100 \mathrm{~mm}$, to the number of dry days and to the monthly largest dry period. The results showed that only days with cumulative rainfall exceeding $50 \mathrm{~mm}$ (July), number of dry days in the month (June) and the monthly largest dry period (May and Nov) were influenced due to the formation of the dam lake.
\end{abstract}

Keys- words: Rainfall, Climate Change, Statistical Tests.

\section{INFLUÊNCIA DO LAGO DA HIDRELÉTRICA DE PASSO FUNDO (RS, BRAZIL) NO COMPORTAMENTO DAS CHUVAS LOCAIS}

RESUMO: O presente trabalho analisou a influência do lago da Usina Hidrelétrica (UHE) de Passo Fundo nas precipitações locais. Foram utilizados dados pluviométricos diários obtidos da Agência Nacional de Águas para dois períodos distintos: 1960-1970 (préenchimento) e 1971-1981 (pós-enchimento). Técnicas estatísticas (média, máximo, mínimo, desvio padrão e coeficiente de variação) foram aplicados aos totais mensais em ambos os períodos, bem como a avaliação das séries pelo teste $t$ de student. $O$ teste $t$ de student também foi aplicado nos dias com precipitações superiores a $1 \mathrm{~mm}, 10 \mathrm{~mm}, 20$ $\mathrm{mm}, 30 \mathrm{~mm}, 50 \mathrm{~mm}, 80 \mathrm{~mm}$ e $100 \mathrm{~mm}$, na quantidade de dias secos no mês e no maior período seco no mês. Os resultados mostraram que apenas os dias com precipitações superiores a $50 \mathrm{~mm}$ (jul), quantidade de dias secos no mês (jun) e o maior período seco no mês (maio e nov) sofreram influência devido a formação do lago da UHE

Palavras-Chave: Chuvas, Mudanças Climáticas, Testes Estatísticos

\section{INTRODUCTION}

Concerns about the influence of artificial lakes on local climatology date back to the early twentieth century (BIGELOW, 1907; 1910; PALMER, 1910; HENRY, 1920). 
Goodland (1977) and, Baxter and Glaude (1980) are considered as the first works that demonstrated environmental impacts due to the formation of hydroelectric dam lakes. In these works, the authors were concerned about environmental issues due to changes in the physical characteristics of nature. These issues involve new dynamic processes and physical, biological, human and economic actions.

Fernandez et al. (1986) studied local changes of airflow caused by the construction of the Arenal Reservoir in Costa Rica, the authors noted that there was an increase in air flow speed after the lake formation.

Sadek et al. (1997) compared methods of estimating evaporation at the Aswan Dam in the Lake Nasser (Egypt). The authors used water-balance, energy budget, bulk aerodynamic, combinated and Complementary Relations Lake Evaporation (CRLE) methods. The results showed that the monthly distribution of the annual evaporation varied more widely according to the applied method. Updating evaporation estimates of Lake Nasser were made by Elsawwaf et al. (2010) using local meteorological and hydrological data from instrumented platforms (floating weather stations) in three locations on the lake.

Brazil has the largest number of Hydroelectric Power Plants (HPP) in operation and the greatest hydraulic head in the world. However, studies on the influence of HPP dam lakes on the local weather, especially rainfall, are still scarce.

Grimm (1988) applied statistical tests (Student's t-test) to a set of data prior and later to the filling of the Itaipu Hydroelectric Power Plant (HPP) lake dam. The results demonstrated an increase in evaporation and minimum temperatures, and a decrease in maximum temperatures during August. In addition, the results show no changes in the monthly rainfall. However, surrounding the Sobradinho HPP, in the northeast semi-arid of Brazil, Campos (1990) studied the variability of rainfall during periods of pre and post-filling. Monthly and percentages of the rainy and dry periods showed that the Sobradinho lake dam influenced on the surroundings rainfall on average of $13 \%$ with an observed peak of $16 \%$ during the rainy season.

Sanches and Fisch (2005) studied the influence of the Tucurui HPP lake dam, located in the Amazon region, on the local rainfall pattern. Statistical tests were applied (Student' T-test, Mann-Whitney $U$ test) to rainfall data prior and later to the lake dam filling. Results showed an increase in the number of days with light rains in the dry period after the dam lake filling.

An important feature described by Campos (1990) and Sanches and Fisch (2015) is that local precipitation's pattern changings were observed through three or four years after hydroelectric dam lake's building. The authors believe that, from a systemic approach, physical conditions of environmental parameters arranged a new energetic balance point, known as entropy process.

The influence of Itá HPP dam lake, located between the states of Rio Grande do Sul and Santa Catarina, was studied by Rodrigues and Canônica (2006), Czarnobai et al. (2006) and Biavatti et al. (2015). The authors observed a decrease in rainfall volumes after the lake filling, probably associated with the variability of ENSO. However, there was an increase in the minimum changes in wind speed and direction caused by the dam formation. 
Barros and Galvani (2010) analyzed the influence of the Eng. Sergio Motta HPP dam lake, between the states of Sao Paulo and Mato Grosso do Sul, on temperatures and air humidity at the city of Presidente Epitácio. The results showed no correlation between the dam lake formation and the variables in any seasons.

Eventually, Silva Filho and Rabelo (2012), and Dantas and Sales (2015) analyzed the influence of the Lake Castanhão, in the state of Ceará, built in 2004 to mitigate drought issues in the northeastern semi-arid. After the application of statistical tests, the results revealed that the temperatures had no changes after the formation of the lake. However, there was an increase in rainfall and relative humidity around the lake after its construction.

This study aimed to identify changes on local rainfall patterns due HPP of Passo Fundo dam lake formation, in the Rio Grande do Sul state, Brazil.

\section{METHODOLOGY}

Daily rainfall data used in this study were obtained from the National Water Agency (2016) at the rainfall gauge station nearby the Passo Fundo HPP dam lake (UHE Passo Fundo Barramento - cod. 2752020) (Fig. 1). The Passo Fundo HPP lake dam was formed in 1971, it has an area of $151.5 \mathrm{~km}^{2}$ (TRACTEBEL ENERGIA, 2016) and it is located at northern part of the Rio Grande do Sul state, Brazil.

According to Köppen's climatic classification (TORRES, 2012), the study zone has a Cfa climate, temperate climate, hot summer and no dry seasons (WOLLMANN and GALVANI, 2012).

In the region, major precipitations occur due to Polar Migratory Anticyclone, which one is responsible for front rains formation. This system is intensified from autumn to winter. During winter, rainfalls on Rio Grande do Sul are originated from frontal cold systems by Polar air mass coming from Antarctic continent - Atlantic Polar airmass (WOLLMANN and GALVANI, 2012).

However, periods of major precipitation occur during spring and autumn, due to Mesoscale Convective Complexe's (MCC) participation (GRIMM et al., 1998)

During summer, Tropical Atlantic airmass (hot and humid) moves from Brazil's center to south region (Rio Grande do Sul state's north), decreasing cold waves and providing increased temperatures, which are responsible for convective rains, deriving from cumulonimbus type clouds. Through this season, rainfalls are also associated to South Atlantic Convergence Zone (SACZ), set up as instability areas, having a Northwest to Southeast orientation, from Amazon to Rio Grande do Sul's coast (BRITTO et al., 2008). 


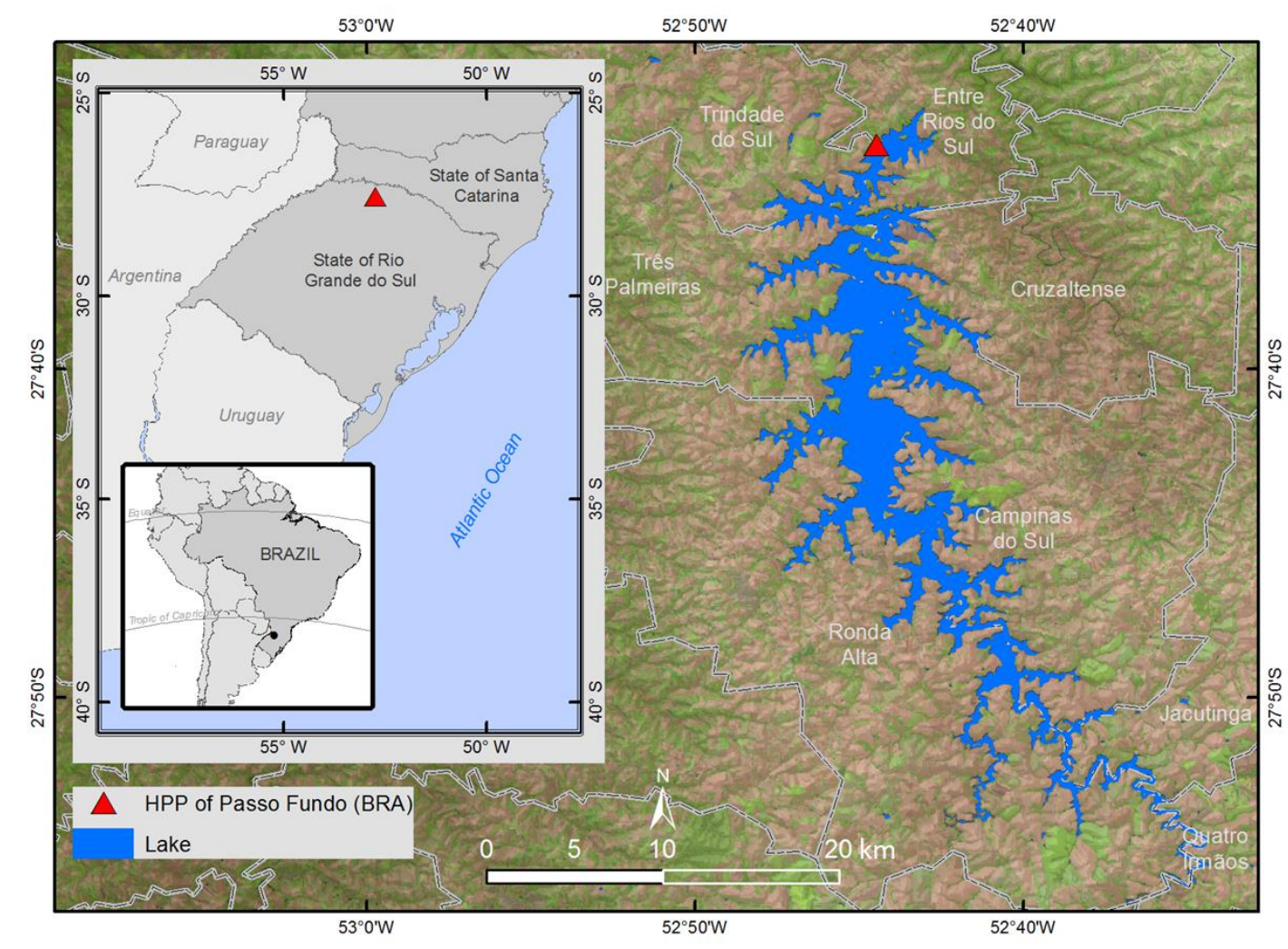

Figure 1 - Hydroelectric Power Plant (HPP) of Passo Fundo dam lake's and the rainfall gauge station's location (Cod. 2752020) (RS, Brazil).

Daily rainfall data from two different periods were used: prior to lake filling, pre-filling (1960-1970) and later to lake filling, post-filling (1971-1981). Initially, the daily data were grouped into monthly totals and statistical measures were applied to both series: mean, maximum, minimum, standard deviation and coefficient of variation.

Afterward, the monthly values were submitted to the Student's t-test, with significance level of $95 \%(a=0.05)$, in order to check the homogeneity between both series (pre and post filling).

Daily records were organized into days with cumulative rainfall less than $1 \mathrm{~mm}, 10 \mathrm{~mm}, 20 \mathrm{~mm}, 30 \mathrm{~mm}, 50 \mathrm{~mm}, 80 \mathrm{~mm}$ and $100 \mathrm{~mm}$. In addition, the greater Length Dry Period per month (LDP/month) and the number of Dry Days in every month (DD) were identified. Daily values of the following classes: $\geq 1 \mathrm{~mm}, \geq 10 \mathrm{~mm} \geq 20 \mathrm{~mm} \geq 30 \mathrm{~mm} \geq 50 \mathrm{~mm} \geq 80 \mathrm{~mm}$ and $\geq 100 \mathrm{~mm}$, DD and LDP/month were submitted to the Student's t-test to check homogeneity between pre and post-filling series.

The null hypothesis ( $\mathrm{HO})$, for the Student's t-test, was assumed that there is no statistical difference between the two datasets $(\mu 1=\mu 2$ e $\sigma 1=\sigma 2)$. However, if the observed results are different from what it is expected by this hypothesis $(\mathrm{HO})$, it can be considered that the differences are statistically significant.

Therefore, 


$$
t=\frac{\mu_{1}-\mu_{2}}{\sigma \sqrt{1 / N_{1}+1 / N_{2}}}
$$

where,

$$
\sigma=\sqrt{\frac{\mathrm{N}_{1} \mathrm{~s}_{1}^{2}+\mathrm{N}_{2} \mathrm{~s}_{2}^{2}}{\mathrm{~N}_{1}+\mathrm{N}_{2}-2}}
$$

and

$$
s^{2}=\frac{\left(\sum_{i=1}^{n} X_{i}-\mu\right)^{2}}{N-1}
$$

In this way, $\mu_{1}$ and $\mu_{2}$ are the monthly averages for the pre and postfilling periods, respectively, $N_{1}$ and $N_{2}$ are the analyzed monthly samples, $\sigma$ is the standard deviation between sets and $s_{1}^{2}$ and $s_{2}^{2}$ their variances of each series. With respect to the degree of freedom, it is adopted:

$$
\mathrm{V}=\mathrm{N}_{1}+\mathrm{N}_{2}-2
$$

Thus, in order to accept the hypothesis $(\mathrm{HO})$, the score ( $\mathrm{z}$ ) of a statistical sample must be between -1.96 and 1.96 , i.e., to consider the null hypothesis, the values must be $-1.96 \leq \mathrm{z} \leq 1.96$.

\section{DISCUSSION AND RESULTS}

\subsection{MONTHLY DATA}

Table I shows the statistical measures for the monthly rainfall in southern Brazil during the pre-filling period: the irregularity of the typical monthly rainfall of the subtropical climate (BRITO et al., 2008; NERY and CARFAN, 2014). In terms of averages, the volume precipitated during the pre-filling period ranged from $106.3 \mathrm{~mm}$ (May) to $198.3 \mathrm{~mm}$ (September). The maximum values ranged from 213.9 (July) to 455.6 (August) where as the minimum values ranged from $13.0 \mathrm{~mm}$ (May) to $99.4 \mathrm{~mm}$ (October). By means of standard deviations and coefficients of variation analysis one can confirm the higher variability, i.e., in more than half, the cumulative monthly rainfall had varied over $50 \%$ 
Table 1 - Cumulative monthly precipitation for the pre-filling period (1960-1970)

\begin{tabular}{|c|c|c|c|c|c|c|c|c|c|c|c|c|}
\hline Years & Jan & $\mathrm{Feb}$ & Mar & $\mathrm{Abr}$ & May & Jun & Jul & Aug & Sep & Oct & Nov & Dec \\
\hline 1960 & 97.6 & 87.6 & 91.4 & 55.8 & 82.6 & 163.0 & 101.4 & 236.8 & 202.6 & 147.8 & 56.5 & 80.8 \\
\hline 1961 & 178.6 & 152.4 & 232.8 & 161.0 & 91.2 & 114.4 & 118.8 & 115.2 & 302.4 & 219.2 & 149.4 & 110.4 \\
\hline 1962 & 140.4 & 80.8 & 112.8 & 51.4 & 226.8 & 34.0 & 180.4 & 81.2 & 124.0 & 146.2 & 133.6 & 87.2 \\
\hline 1963 & 306.4 & 67.4 & 274.2 & 81.2 & 124.8 & 141.0 & 109.2 & 160.8 & 271.0 & 214.4 & 307.0 & 109.0 \\
\hline 1964 & 103.0 & 107.2 & 125.2 & 360.6 & 36.6 & 41.4 & 97.0 & 256.0 & 152.0 & 113.0 & 62.2 & 154.4 \\
\hline 1965 & 63.8 & 157.0 & 59.6 & 218.4 & 62.2 & 51.4 & 124.4 & 455.6 & 353.0 & 177.6 & 98.8 & 219.0 \\
\hline 1966 & 191.8 & 215.2 & 100.6 & 20.8 & 13.0 & 263.6 & 186.2 & 277.2 & 202.4 & 288.7 & 87.4 & 191.5 \\
\hline 1967 & 132.8 & 106.9 & 170.5 & 43.2 & 94.3 & 74.1 & 213.9 & 279.9 & 198.9 & 192.4 & 129.5 & 63.2 \\
\hline 1968 & 134.2 & 88.1 & 115.9 & 154.1 & 23.0 & 82.6 & 108.4 & 16.8 & 156.6 & 167.2 & 142.8 & 137.2 \\
\hline 1969 & 226.4 & 177.6 & 88.2 & 116.0 & 177.6 & 133.0 & 72.4 & 58.2 & 92.1 & 99.4 & 215.8 & 132.0 \\
\hline 1970 & .7 & .0 & 1. & .8 & 7.6 & .8 & 58.0 & .4 & .4 & 170.6 & 54.8 & 300.8 \\
\hline Mean & 146.9 & 127.7 & 135.7 & 122.7 & 106.3 & 123.7 & 133.6 & 184.3 & 198.3 & 176.0 & 130.7 & 144.1 \\
\hline Max. & 306.4 & 215.2 & 274.2 & 360.6 & 237.6 & 263.6 & 213.9 & 455.6 & 353.0 & 288.7 & 307.0 & 300.8 \\
\hline Min. & 40.7 & 67.4 & 59.6 & 20.8 & 13.0 & 34.0 & 72.4 & 16.8 & 92.1 & 99.4 & 54.8 & 63.2 \\
\hline Std. Dev & 76.0 & 47.8 & 65.0 & 98.8 & 77.8 & 80.5 & 44.3 & 129.7 & 81.2 & 52.9 & 75.9 & 69.9 \\
\hline CV (\%) & 52 & 37 & 48 & 81 & 73 & 65 & 33 & 70 & 41 & 30 & 58 & 49 \\
\hline
\end{tabular}

Source: National Water Agency (ANA). Organized by the authors.

Table II (post-filling period) shows a similar behavior as shown in Table I (pre-filling period). The same variability can be observed in the mean values of the period, especially for the April month, which presented values below 100 $\mathrm{mm}$. However, such condition confirms the typical variability of monthly rainfall for the study region. The same behavior (high variability) may be observed in the maximum and minimum values of the post-filling period. Standard deviations and coefficients of variation confirm the peculiar dynamic variability of the cumulative monthly rainfall as well. 
Table 2 - Cumulative monthly precipitation for the post-filling period (1971-1981)

\begin{tabular}{|c|c|c|c|c|c|c|c|c|c|c|c|c|}
\hline Years & Jan & Feb & Mar & $A b r$ & May & Jun & Jul & Aug & Sep & Oct & Nov & Dec \\
\hline 1971 & 195.4 & 244.8 & 157.1 & 188.6 & 139.9 & 297.2 & 125.5 & 220.8 & 123.0 & 83.2 & 52.6 & 116.4 \\
\hline 1972 & 230.6 & 191.8 & 178.2 & 176.6 & 87.4 & 430.6 & 171.1 & 402.0 & 366.2 & 122.2 & 218.0 & 101.0 \\
\hline 1973 & 280.2 & 172.4 & 206.6 & 129.2 & 258.2 & 241.2 & 313.2 & 241.0 & 171.8 & 197.2 & 99.6 & 211.8 \\
\hline 1974 & 156.2 & 112.8 & 120.2 & 48.2 & 216.2 & 206.6 & 43.6 & 94.8 & 33.4 & 108.8 & 177.0 & 214.8 \\
\hline 1975 & 169.8 & 116.6 & 206.6 & 80.4 & 52.8 & 153.8 & 92.0 & 191.0 & 214.5 & 184.2 & 147.6 & 205.8 \\
\hline 1976 & 300.6 & 153.4 & 73.8 & 69.8 & 159.0 & 58.2 & 159.6 & 156.4 & 170.6 & 172.2 & 276.6 & 214.3 \\
\hline 1977 & 198.4 & 183.7 & 139.8 & 24.8 & 92.4 & 281.6 & 197.9 & 208.3 & 118.6 & 119.8 & 270.4 & 93.8 \\
\hline 1978 & 120.6 & 33.4 & 155.0 & 27.2 & 35.8 & 98.5 & 193.5 & 77.2 & 166.6 & 141.3 & 157.4 & 148.6 \\
\hline 1979 & 22.8 & 181.6 & 135.8 & 158.4 & 226.0 & 64.4 & 236.4 & 175.8 & 142.3 & 396.4 & 122.6 & 255.0 \\
\hline 1980 & 93.4 & 164.6 & 121.5 & 36.2 & 216.4 & 66.8 & 156.0 & 161.4 & 132.8 & 172.1 & 195.6 & 150.0 \\
\hline 1981 & 175.4 & 121.4 & 61.2 & 137.0 & 35.4 & 164.0 & 44.8 & 119.8 & 125.8 & 100.6 & 153.6 & 253.0 \\
\hline Mean & 176.7 & 152.4 & 141.4 & 97.9 & 138.1 & 187.5 & 157.6 & 186.2 & 160.5 & 163.5 & 170.1 & 178.6 \\
\hline Max. & 300.6 & 244.8 & 206.6 & 188.6 & 258.2 & 430.6 & 313.2 & 402.0 & 366.2 & 396.4 & 276.6 & 255.0 \\
\hline Min. & 22.8 & 33.4 & 61.2 & 24.8 & 35.4 & 58.2 & 43.6 & 77.2 & 33.4 & 83.2 & 52.6 & 93.8 \\
\hline Std. Dev & 80.0 & 55.2 & 47.1 & 61.9 & 82.3 & 118.0 & 80.4 & 88.1 & 81.9 & 85.7 & 68.1 & 58.8 \\
\hline CV (\%) & 45 & 36 & 33 & 63 & 60 & 63 & 51 & 47 & 51 & 52 & 40 & 33 \\
\hline
\end{tabular}

Source: National Water Agency (ANA). Organized by the authors.

Accordingly, the statistics of monthly totals for both periods showed no change on rainfall pattern due to the formation of the dam lake. The results from Student's t-test application for the monthly totals (Tab. III) confirms the homogeneity of data sets pre and post-filling.

Table 3 - The statistic results of Student's t-test for the monthly totals (pre and postfilling)

\begin{tabular}{|c|c|c|c|c|c|c|c|c|c|c|c|c|}
\hline & Jan & Feb & Mar & $\mathrm{Abr}$ & May & Jun & Jul & Aug & Sep & Oct & Nov & Dec \\
\hline $\begin{array}{l}\text { Sco } \\
\text { rez }\end{array}$ & -0.79 & -1.18 & -0.25 & 0.72 & -1.03 & -1.73 & -1.05 & -0.03 & 1.25 & -0.37 & -1.38 & -1.60 \\
\hline
\end{tabular}

\subsection{DAILY DATA}

Regarding the daily data, the application of the Student's t-test revealed that the daily precipitation classes equal to or greater than $1,10,20,30,80$ and $100 \mathrm{~mm}$ were statistically homogeneous (Tab. IV). 
Table 4 - Result from the statistical Student's t-test application for the daily precipitation classes

\begin{tabular}{lccccccccccccc}
\hline & Jan & Feb & Mar & Abr & May & Jun & Jul & Aug & Sep & Oct & Nov & Dec \\
\hline$\geq 1 \mathrm{~mm}$ & -0.78 & -0.07 & -0.42 & 0.95 & -1.75 & -1.84 & -1.47 & -1.50 & 0.78 & 0.22 & -1.14 & -0.92 \\
$\geq 10 \mathrm{~mm}$ & -0.85 & -0.11 & -0.36 & 1.10 & -1.59 & -1.74 & -1.34 & -0.68 & 1.15 & 0.62 & -1.72 & 0 \\
$\geq 20 \mathrm{~mm}$ & -0.77 & -1.86 & 1.43 & 0.39 & -1.22 & -1.15 & -0.90 & 0.36 & 1.26 & 0.26 & -1.79 & 0.39 \\
$\geq 30 \mathrm{~mm}$ & -0.95 & -1.70 & -0.42 & 0.16 & 0.16 & -0.53 & -1.25 & 0.09 & 1.65 & 0.19 & -1.46 & -1.32 \\
$\geq 50 \mathrm{~mm}$ & -0.72 & 0 & -1.29 & 1.18 & 0.23 & -1.02 & 2.51 & 0.41 & 0.49 & 0.35 & 0.77 & -0.42 \\
$\geq 80 \mathrm{~mm}$ & null & null & 0 & -1.49 & 0 & -1.08 & -1.00 & 0.45 & 0.60 & 0 & -0.60 & -1.37 \\
$\geq 100 \mathrm{~mm}$ & null & null & 1.00 & 1.00 & -1.00 & -1.08 & -1.00 & 1.00 & 0 & 0 & -1.00 & 1.00 \\
DD & 0.78 & -0.07 & 0.42 & -0.95 & 1.75 & 1.99 & 1.47 & 1.50 & -0.78 & -0.15 & 1.14 & 1.00 \\
LDD/month & -0.28 & 0.89 & 1.04 & -0.51 & 2.47 & 1.34 & 1.30 & -0.89 & -0.44 & 0.18 & 2.14 & 1.57 \\
\hline
\end{tabular}

DD: number of dry days in the month; LDD/month: greater length of dry days in the month.

The Student's t-test showed that in July, days with precipitation $\geq 50 \mathrm{~mm}$ underwent significant modifications regarded to behavioral changes. Figure 2 shows that there was a reduction in the number of days with rainfall, in this category, after the formation of the HPP of Passo Fundo dam lake.).

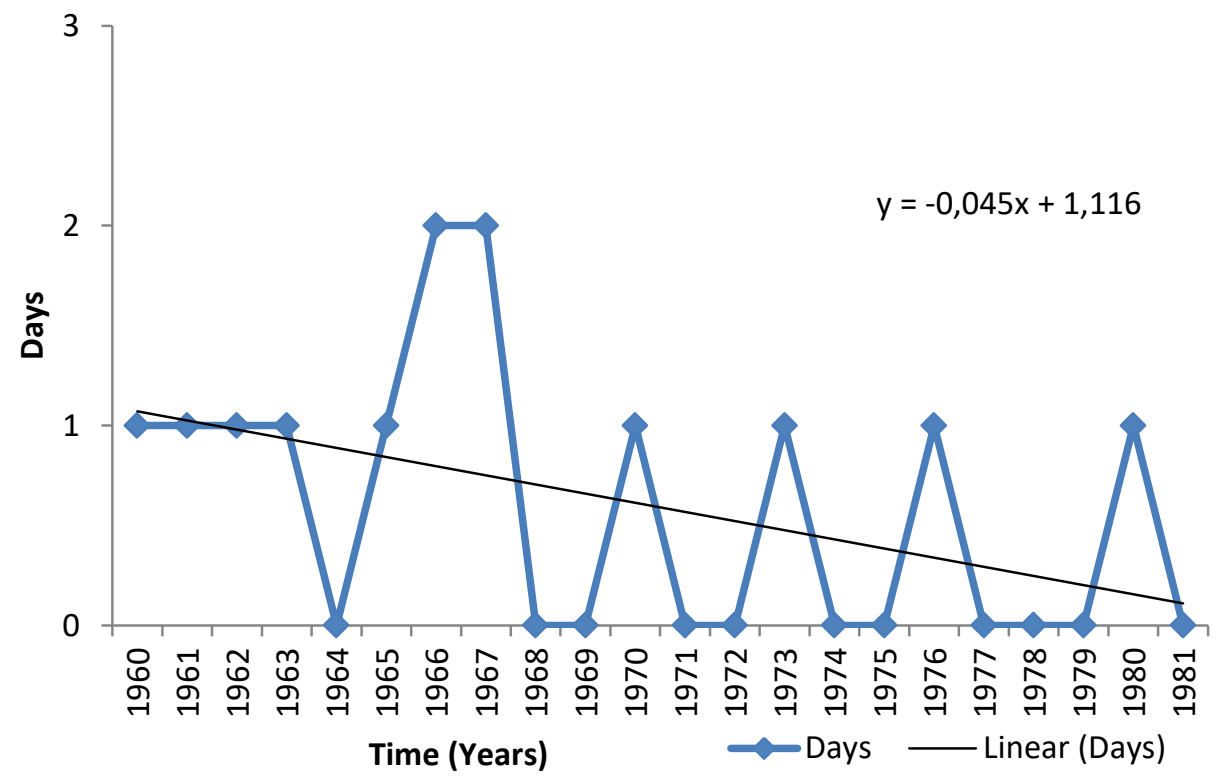

Figure $\mathbf{2}$ - Days with rainfall $\geq 50 \mathrm{~mm}$ for the month of July

Although OMM's (2011) recommendation for climatic characterization (pluviometric) of a zone considers a minimum period of thirty years, the building of an artificial lake, which has an $151.5 \mathrm{~km}^{2}$ area, is capable of promoting changes on local precipitation process, due to the fact that surface changes modifies its energy balance (SILVA, 2015). Campos (1990) and Sanches and Fisch (2015) claim that these modifications occur, essentially, during first periods after hydroelectric lake's building. 
By means of comparison of the observed results with information from National Oceanic and Atmospheric Administration (NOAA) on the occurrence of ENSO, it appears at the beginning of 1970s, there was a La Niña phenomenon predominance in July. This condition may have influenced the reduction on the number of days with rain $\geq 50 \mathrm{~mm}$.

Rao and Hada (1990), and Grimm et al. (2000) stated that the South and Southeast regions of South America are areas heavily affected by the warm phases (EI Niño) and cold phases (La Niña) of ENSO. During the warm phases, rainfall is more intense and frequent, whereas during the cold phase, rainfall becomes scarcer.

For Nery and Carfan (2014), although the South region of Brazil presents rains above the climatological average during the El Niño years, every year under the warm phase (El Niño) produces no same response to the rains. However, Chechi and Sanches (2013), analyzing the rains in the Alto Uruguay Gaúcho area, where is located the Passo Fundo HPP, found that the years classified as dry and very dry, according to the Rains Anomaly Index (RAI), had low correspondence to the years of the cold phase of ENSO (La Niña).

Student's t-test results analysis, for dry days in June and their behavior throughout the series (Fig. 3a), indicated the possibility HPP of Passo Fundo dam lake has influenced the reduction of dry days. According to the test, there is a significant difference between the pre and post-filling periods, as seen in Fig. $3 \mathrm{~b}$. It is appropriate to point out that the years 1971 and 1973 were years under the influence of the cold phase of ENSO (La Niña). During the summer 71/72, the ENSO manifested itself in its warm phase (El Niño).

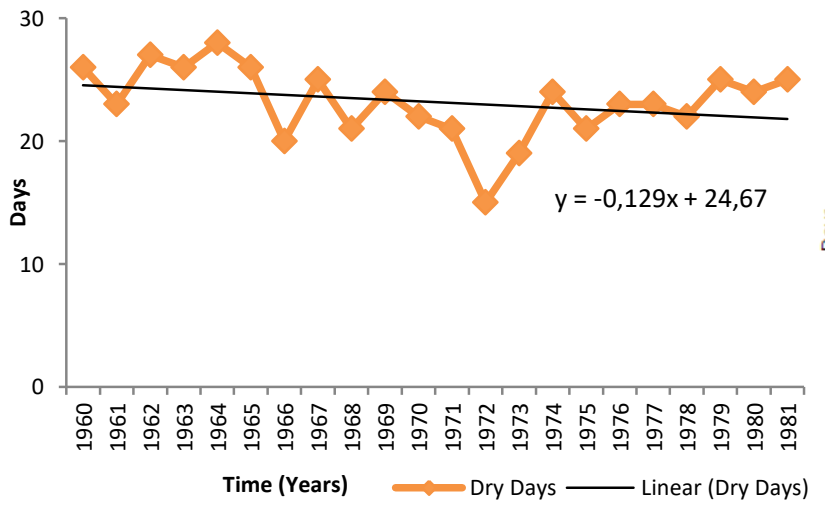

(a)

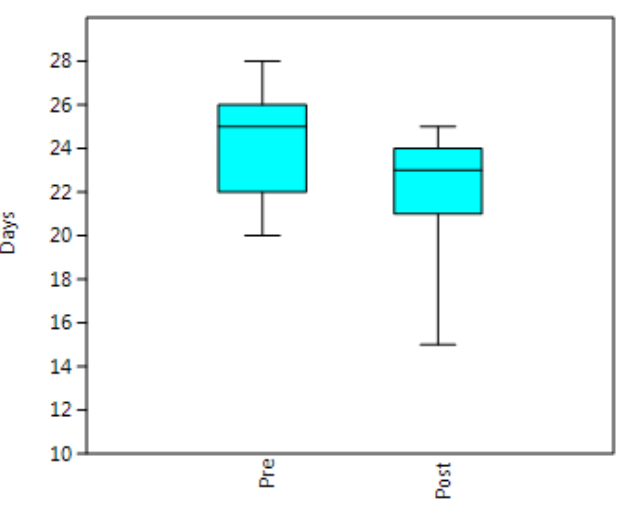

(b)

Figure 3 - Dry Days (DD) for the months of June.(a) Time-series and linear trend. (b) Box-plot of pre and post-filling periods

Likewise, the Student's t-test results for the LDP/month applied to the months of May and November indicated differences between pre and post-filling series (Fig. 4c and 4d). Figures $4 a$ and $4 b$ show a downward trend for LDP/month for both months. 


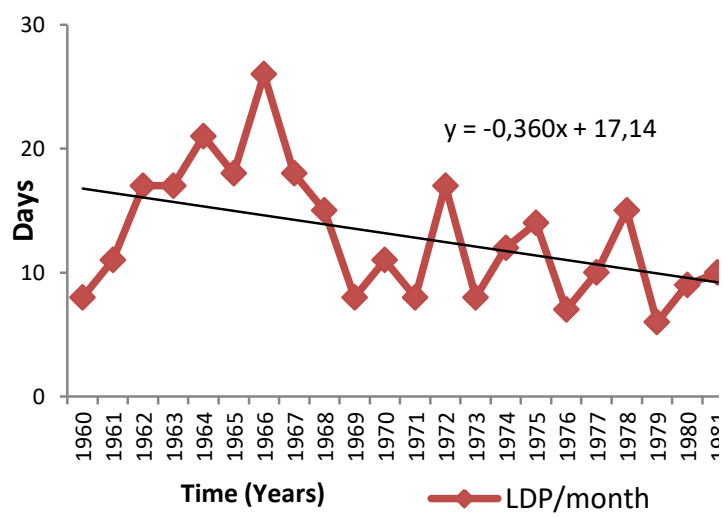

(a)

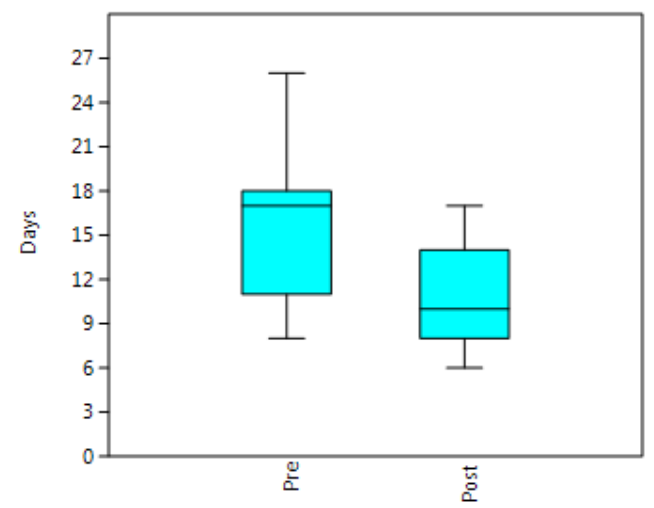

(c)

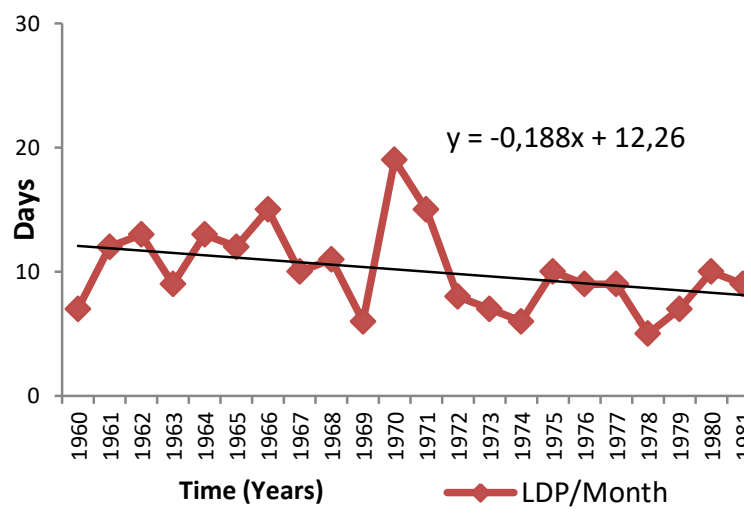

(b)

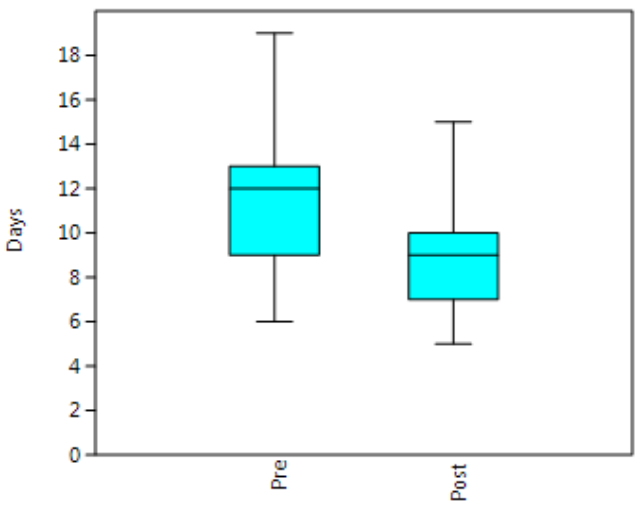

(d)

Figure 4 - Increased in Length Dry Period in the month (LDP/month). (a) Time series for May. (b) Time series for November. (c) Box-plot pre and post-filling periods for May. (d) Box-plot pre and post-filling periods for November.

The formation of the HPP of Passo Fundo dam lake has contributed to the reduction of LDP/month in May and November as the availability of water in a free surface favors evaporation. Therefore, the interval between rain events would be reduced in time.

Table $\mathrm{V}$ demonstrates that although the first years after the formation of the dam lake were under the effect of La Niña (Drier), from 1976 the November months were under the influence of El Niño (Rainier). However, the trend of reduced LDP/month remains negative (Fig. 4a and $4 \mathrm{~b}$ ) allowing one to consider that ENSO had little influence on the data set. 
Table 5 - Quarterly ranking of ENSO

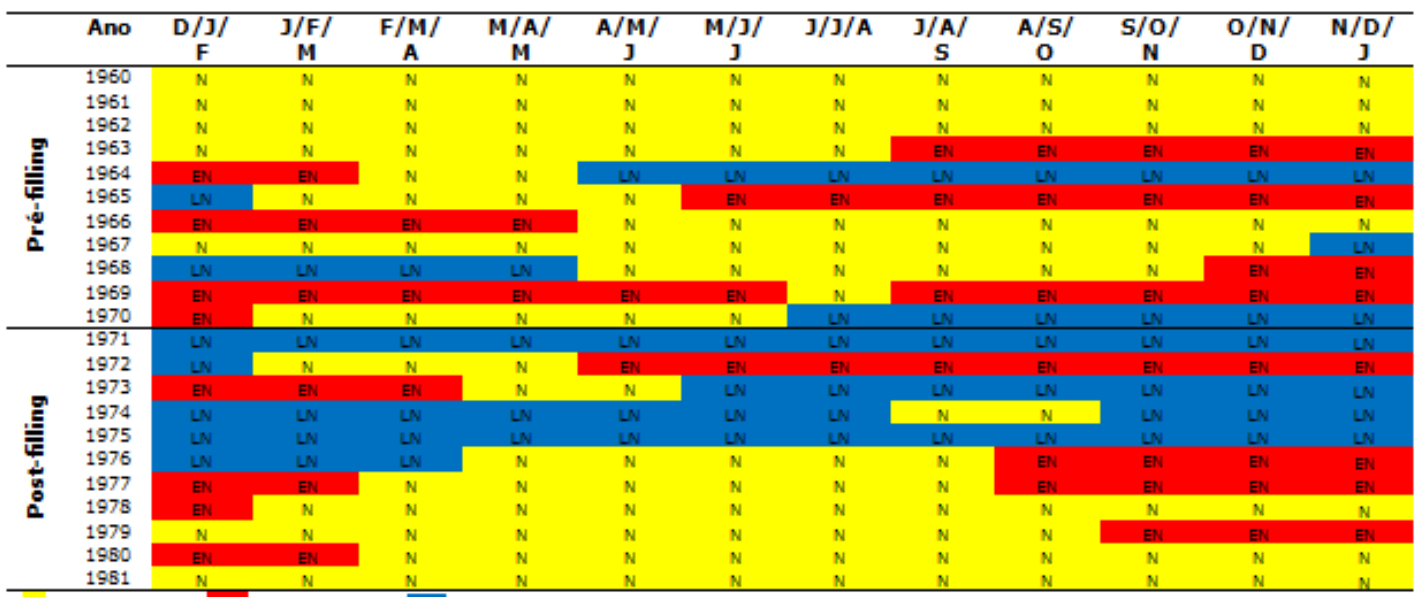

N: Neutral; EN: El Niño; LN: La Niña

Source: Adapted from NOAA

(http://www.cpc.ncep.noaa.gov/products/analysis monitoring/ensostuff/ensoyears.shtml)

\section{CONCLUSIONS}

Statistical analysis of the monthly total rainfall (mean, maximum, minimum, standard deviation and coefficient of variation), before and after the formation of the Passo Fundo HPP of Passo Fundo dam lake, showed very similar characteristics mostly due to strong variability, characteristic of monthly rainfall in the subtropical part of the Brazilian territory.

The Student's t-test results showed the formation of the dam lake produced no changes on the behavior of subsequent monthly rainfall after the lake formation. In addition, the evaluation of days with precipitation equal to or greater than $1,10,20,30,80$ and $100 \mathrm{~mm}$ suggests that there were no significant changes due to the dam lake formation. However, the results of statistical tests demonstrated that the precipitation days $\geq 50 \mathrm{~mm}$ decreased in the post-filling period.

The analysis of the higher monthly Length Dry Period (LDP/month) and the amount of Dry Days (DD) for every month showed a downward trend after the lake formation. This trend finds no correspondence with the dynamics of cold and warm phases of ENSO. The months of May and November showed significant decrease in these parameters, according to the Student's t-test application. These results reveal that the HPP of Passo Fundo dam lake contributed to the decrease of dry days, thereby reducing the interval between rainy days.

Therefore, it is possible to consider that, contradicting the most of the literature results on the subject, the formation of HPP of Passo Fundo dam lake had little influence on the behavior of rainfall. However, the results found here, should not be extrapolated to other cases without proper study of its climatological variables. 


\section{ACKNOWLEDGEMENTS}

The authors express their gratitude to the Dean of Research and Graduate Studies at the Federal University of Fronteira Sul for financial support. The authors also thank FAPERGS (grant no. 002073-2551/13-1) and CNPq (grant no. 460329/2014-6) for the support.

\section{REFERENCES}

BIAVATI, A.; FAGUNDES, R.A.; SOUZA, D.; SANCHES, F. A influência do lago da UHE de Itá nas precipitações mensais em Marcelino Ramos (RS). In: XVI Simpósio Brasileiro de Geografia Física Aplicada. Anais... Teresina (PI). 2015.

BIGELOW, F.H. Studies on the phenomena of the evaporation of water over lakes and reservoirs. Monthly Weather Review. 35. p, 311-316, 1907.

BIGELOW, F.H. Studies on the phenomena of the evaporation of water over lakes and reservoirs. Monthly Weather Review. 38. 307-313. 1910.

BRITO, F.P.; BARLETTA, R.; MENDONÇA, M. Regionalização sazonal e mensal da precipitação pluvial máxima no estado do Rio Grande do Sul. Revista Brasileira de Climatologia. v.3 (3/4), 83-99, 2008.

CAMPOS, F.S. Estudo de variabilidade de precipitação. Instituto Tecnológico de Aeronáultica. São José dos Campos. 1990. 56pp.

CHECHI, L.; SANCHES, F.O. O Uso do Índice de Anomalia de Chuva (IAC) na avaliação do Fenômeno do El Niño Oscilação Sul (ENOS) no Alto Uruguai Gaúcho entre 1957-2012. Revista Brasileira de Geografia Física. 06. 1586-1597. 2013.

CZARNOBAI, A.F.; PRUDENCIO, R.S.; RODRIGUES, M.L.G. A circulação atmosférica loca na região da Usina Hidrelétrica de Itá. In: XIV Congresso Brasileiro de Meteorologia. Florianópolis. Anais... 2006.

DANTAS, S.P.; SALES, M.C.L. A Influência do Açude Castanhão no Clima Local de Jaguarema - Ceará - Brasil: Uma análise no campo térmico e higrométrico. Revista Equador. 4.2-17. 2015.

ELSAWWAF, M.; WILLEMS, P.; PAGANO, A.; BERLAMONT, J. Evaporation estimates from Nasser Lake. Egypt. based on three floating station data and Bowen ratio energy budget. Theoretical and Applied Climatology. 100. 439-465. 2010.

FERNANDEZ, W.; CHACÓN, R. E.; MELGAREJO, E.E.J.W. Modifications of Air Flow Due to the Formation of a Reservoir. Journal of Climate and Applied Meteorology. 25. 982-988. 1986.

GOODLAND, R. J. A. Environmental optimization in hydrodevelopment of tropical forest regions. In. Man-made lakes and human healthy. Paramaribo. Suriname. Proceedings of the symposium on man-made and human healthy. Faculty of Medicien. University of Suriname. Paramaribo: ed. Panday R.S. 73. 1977.

GRIMM, A.M. Verificação de Variações Climáticas na área do Lago de Itaipu - In: XII Congresso Brasileiro de Meteorologia. Anais.... Rio de Janeiro. 1998. 
GRIMM, A.M.; BARROS, V.R.; DOYLE, M. E. Climate Variability in Southern South America Associated with El Niño and La Niña Events. Journal of Climate. 1. 3558. 2000.

GRIMM, A.M.; FERRAZ, S.E.T; GOMES, J. Precipitation Anomalies in Southern Brazil Associated with El Niño and La Niña Events. Journal of Climate, v.11, p.2863-2880, 1998.

HAMMER Ø.; HARPER,D.A.T.; RYAN, P.D. PAST: Paleontological Statistics Software Package for Education and Data Analysis. Palaeontologia Electronica 4(1): 2001. 9pp. Available in:< http://palaeoelectronica.org/2001_1/past/issue1_01.htm> Accessed on: November 2, 2015.

HENRY, A. J. Would a large reservoir increase rainfall? Monthly Weather Review. 48.31-32. 1920.

NATIONAL WATER AGENCY (Agência Nacional de Águas in Portuguese), 2016 Available in: <http://www.snirh.gov.br/hidroweb> Accessed in: January 10, 2016.

NERY, J.T.; CARFAN, A.C. Re-analysis of pluvial precipitation in southern Brazil. Atmósfera, 27. 103-115. 2014.

NATIONAL OCEANIC AND ATMOSPHERIC ADMINISTRATION - National Weather Service - Climate Prediction Center - El Niño Southern Oscillation (http://www.cpc.ncep.noaa.gov/products/analysis_monitoring/ensostuff/ensoyea rs.shtml)

Organizacion Meteorológica Mundial (OMM). Guía de prácticas climatológicas. OMM no 100, 2011.

PALMER, W. S. The shoshone reservoir. Monthly Weather Review. 38. 394-395. 1910.

RAO V. B.; HADA, K. Characteristics of rainfall over Brazil: Annual variations and connections with the southern oscillations. Theoretical and Applied Climatology. 42. 81-91. 1990.

RODRIGUES, M.L.G.; CANÔNICA, E. Análise preliminar do impacto do reservatório de Itá no clima local. In: XIV Congresso Brasileiro de Meteorologia. Anais... Florianópolis. 2006.

SADEK, M. F.; SHAHIN, M.M.; STIGTER, C. J. Evaporation from the reservoir of the High Aswan Dam. Egypt: A new comparison of relevant methods with limited data. Theoretical and Applied Climatology. 56.57-66. 1997.

SANCHES, F.; FISCH, G. As possíveis alterações microclimáticas devido a formação do lago artificial da hidrelétrica de Tucuruí-PA. Acta Amazonica. 35. p. 41-50. 2005.

SILVA, J.M. O homem, meio ambiente, antropia e entropia: passado e presente de uma relação tensa. Revista Diálogos n.14, ago./ set., 2015.

SILVA FILHO, V.; RABELO, J.K.L. Detecção de possíveis diferenças ocorridas no comportamento da atmosfera local como consequência da introdução do lago Castanhão no estado do Ceará. In: XVII Congresso Brasileiro de Meteorologia. Anais... Gramado-RS. 2012. 
SOUZA, M. B.; GALVANI, E. Formação de reservatórios e influências no microclima: estudo da cidade de Presidente Epitácio. Estado de São Paulo. Brasil. In: VI Seminário Latino-ameriano de Geografia Física e II Seminário Iberoamericano de Geografia Física. Anais... Coimbra. Portugal. 2010.

TRACTEBEL ENERGIA, 2016.2 Available in: <http://www.tractebelenergia.com.br> Access in: January 10, 2016.

TORRES, F.T.P.; MACHADO, P.J.O. Introdução à Climatologia. Ed. Cengarge Learning, 2012.

WOLLMANN, C.; GALVANI, E. Caracterização climática regional do Rio Grande do Sul: dos estudos estáticos ao entendimento da gênese. Revista Brasileira de Climatologia. v.11 - jul/dez, 2012. 